Jurnal Keperawatan, Volume 9, No. 2, Agustus 2021, (Hal. 24-32)

\title{
HUBUNGAN PENGALAMAN KERJA PERAWAT DENGAN PERSPEKTIF KOLABORASI PERAWAT-DOKTER DI RSU GMIM PANCARAN KASIH
}

\author{
Trisca J.V Sinubu ${ }^{a}$, Lenny Gannika ${ }^{b}$, Andi Buanasari ${ }^{c}$ \\ ${ }^{a-c}$ Program Studi Ilmu Keperawatan, Fakultas Kedokteran, Universitas Sam Ratulangi \\ *Corresponding author: jessysinubu96@gmail.com
}

\begin{abstract}
Collaboration between the nursing profession and doctor profession is influenced by work experience in the success of the quality of health services provided to patients in hospital. This study aims to to find the correlation between nurse work experience and collaborative perspective between nurse-doctor in RSU Gmim Pancanran Kasih of manado. type of in the studyis analytic research by using cross sectional approach. Sampling in this study using simple random sampling method. The sample is determined using the Slovin formula, this study involved 114 respondents. The instrument in this study used questionnaire with ordinal measuring scale. The data analysis using the chi-square test, the results of the Chi-Square test obtained $\rho$ value $=0.008<0.05$, indicated that there is a relationship between work experience and a collaborative nurse-doctor perspective in RSU Gmim Pancanran Kasih of manado. The work experience at Gmim Pancaran Kasih Hospital is categorized as good, thus, the collaborative perspective of nurses - doctors is identified in a good level.
\end{abstract}

Keywords: Keywords : Work experience; Nurse-Doctor Collaboration; Nurse

\begin{abstract}
Abstrak
Kolaborasi antara profesi perawat dengan profesi dokter dipengaruhi oleh pengalaman kerja dalam keberhasilan dari kualitas pelayanan kesehatan yang diberikan kepada pasien di rumah sakit. Penelitian ini bertujuan untuk mengetahui hubungan pengalaman kerja perawat dengan perspektif berkolaborasi antara perawat-dokter di RSU Gmim Pancanran Kasih. Jenis penelitian yang digunakan,yaitu penelitian analitik dengan pendekatan cross sectional. Pengambilan sampel dalam penelitian ini menggunakan metode simple random sampling. Sampel ditentukan menggunakan rumus Slovin, sampel yang diperoleh berjumlah 114 . Instrument penelitian yang digunakan adalah kuesioner dengan skala ukur ordinal. Analisis data menggunakan uji chi-square, hasil uji Chi-Square diperoleh $\rho$ value $=0,008<0,05$ maka disimpulkan terdapat Hubungan Pengalaman Kerja Perawat Dengan Perspektif Berkolaborasi Perawat - Dokter di RSU Gmim Pancaran Kasih Manado. Pengalaman kerja yang ada di RSU Gmim pancaran kasih manado dikategorikan baik, sehingga Perspektif Berkolaborasi Perawat - Dokter yang di dapatkan adalah baik.
\end{abstract}

Kata kunci: Pengalaman Kerja; kolaborasi perawat-dokter; Perawat 


\section{PENDAHULUAN}

Perawatan kesehatan merupakan salah satu hal yang masih terus dikembangkan saat ini. Istilah kolaborasi antar profesi merupakan salah satu sistem yang terus dikembangkan agar pasien mendapatkan pelayanan kesehatan yang komprehensif. Berbagai definisi kolaborasi banyak dikemukakan, diantaranya menurut Henderson (1991. yang mendefinisikannya sebagai kerjasama antara tenaga kesehatan (Dokter, Perawat, tenaga kesehatan lain) dengan pasien dan keluarganya untuk mencapai tujuan. Kolaborasi juga dapat didefinisikan sebagai hubungan timbal balik dimana pemberi pelayanan memegang tanggung jawab paling besar untuk perawatan pasien dalam kerangka kerja bidang respektif mereka. Praktik kolaborasi menekankan tanggung jawab bersama dalam menajemen perawatan pasien, dengan proses pembuatan keputusan bilateral didasarkan pada masingmasing pendidikan dan kemampuan praktisi (American Nurses Association, 1992 dalam mutu pelayanan kesehatan.net). Meskipun banyak definisi yang disampaikan, namun inti dari upaya kolaborasi ini untuk memberikan pelayanan yang bermutu dan terbaik bagi pasien.

Kolaborasi Interprofesi atau Interprofessional Collaboration (IPC) adalah kemitraan antara orang dengan latar belakang profesi yang berbeda dan bekerja sama untuk memecahkan masalah kesehatan dan menyediakan pelayanan kesehatan (Morgan et al, 2015). Menurut WHO, IPC terjadi saat berbagai profesi kesehatan bekerja sama dengan pasien, keluarga dan komunitas untuk menyediakan pelayanan komprehensif dan berkualitas tinggi (WHO, 2010). IPC dimaksudkan untuk mencapai tujuan dan memberi manfaat bersama bagi semua yang terlibat (Ridar \& Santoso, 2018).

Kolaborasi interprofesi merupakan kerja sama antar profesi kesehatan dari latar belakang profesi yang berbeda dengan pasien dan keluarga pasien untuk memberikan kualitas pelayanan yang terbaik (WHO, 2010). Hubungan kolaborasi interprofesi dalam pelayanan kesehatan melibatkan sejumlah profesi kesehatan, namun kolaborasi antara dokter dan perawat merupakan faktor penentu yang sangat penting bagi kualitas proses perawatan (Barrere and Ellis, 2002). Fenomena yang ada saat ini kolaborasi antara perawat dengan dokter belum berjalan sesuai dengan yang diharapkan karena masing-masing cenderung mengutamakan kepentingan hubungan dengan pasien, kurang memperhatikan hubungan perawat dengan dokter (Martiningsih, 2011).

Peningkatan kualitas pelayanan terhadap pasien harus memperhatikan manajemen perawatan pasien yang dikelola oleh dokter, perawat dan tenaga kesehatan lainnya yang harus berkolaborasi, berkoordinasi, bekerjasama saling memberikan informasi dan mempunyai tujuan bersama yaitu kesembuhan pasien. Hubungan perawat dan dokter adalah dua profesi yang memiliki peran cukup signifikan dalam memberikan layanan kesehatan kepada pasien (Anggarawati dan Sari, 2016).Salah satu tujuan kolaborasi adalah memberikan pelayanan kesehatan yang berkualitas dengan menggabungkan keahlian unik dari masing-masing profesi, untuk menggabungkan keahlian unik ini dibutuhkan kesadaran dan kemampuan dari masing-masing profesi, kurangnya kesadaran dan kemampuan dalam berkolaborasi dapat menimbulkan dampak yang buruk terhadap kualitas layanan yang diberikan (Martiningsih, 2011).

Beberapa penelitian menunjukkan bahwa ada beberapa aspek positif yang dapat ditimbulkan bila hubungan kolaborasi dokter-perawat berlangsung baik. American Nurses Credentialing Center (ANCC) melakukan risetnya pada 14 rumah sakit melaporkan tentang hubungan dokterperawat bukan hanya mungkin dilakukan, tetapi juga berdampak langsung pada hasil yang dialami pasien. Terdapat hubungan korelasi positif antara kualitas hubungan dokter-perawat dengan kualitas hasil yang didapatkan pasien. Bekerja sama dalam memberikan pelayanan kepada pasien tentunya saling menghargai dan menghormati peran dan fungsi profesi, mempunyai kekuasaan atau wewenang secara profesional, saling memberikan 
informasi antar disiplin ilmu, mempunyai kepentingan serta tujuan bersama (Anggarawati dan Sari, 2016).

WHO pada tahun 2010 mengeluarkan kerangka aksi untuk pendidikan interprofesi dan praktik kolaborasi (Framework for action on interprofessionaleducation and collaborative practice) mengidentifikasi mekanisme yang membentuk kesuksesan kerja sama tim kolaborasi dan menguraikan serangkaian tindakan yang dapat diterapkan dalam sistem kesehatan setempat. Kolaborasi interprofesi merupakan strategi yang efektif dan efisien untuk meningkatkan kualitas pelayanan dan hasil kesehatan pasien dengan semakin beragamnya profesi di bidang kesehatan dan semakin kompleksnya permasalahan pasien.

Banyak faktor yang memengaruhi atau menghambat pelaksanaan kolaborasi diantaranya adalah faktor sosial, institusional, faktor ekonomi, kemampuan klinik dan kemampuan menjalin hubungan interpersonal, dalam memahami konsep kolaborasi para ahli teori organisasi menurut Sullivan (1998) mengusulkan bahwa perilaku dalam penanganan konflik dapat digunakan untuk menilai praktik kolaborasi yang dapat dilihat dari 2 dimensi yaitu tingkat ketegasan atau asertif dan kerja sama atau kooperatif (Martiningsih, 2011).

Berbagai penelitian telah dilakukan sehubungan dengan masalah hubungan kolaborasi antara perawat dan dokter. Beberapa yang telah terpublikasi berfokus pada hubungan kolaborasi perawat dan dokter dalam rumah sakit, khususnya pada area keperawatan kritis seperti Intensive Care Units (ICU). Penelitian Knaus et al mengatakan bahwa pada 13 ruang ICU di Amerika Serikat ditemukan penurunan rasio angka kematian berhubungan dengan peningkatan interaksi dan kolaborasi antara perawat dan dokter (Martiningsih, 2011).

Hasil penelitian menjelaskan bahwa praktik kolaborasi perawat dengan dokter berimbas pada penurunan biaya perawatan $25 \%$, dan penurunan lama hari perawatan 39,8\% (Sulivan, 1998 dalam Martiningsih, 2011). Pendidikan keperawatan di Indonesia yang diawali dari pendidikan yang bersifat vokasional (SPK atau Sekolah Perawat
Kesehatan, DIII Keperawatan, DIV keperawatan) berkembang ke arah pendidikan keperawatan yang bersifat profesional yaitu Pendidikan S1 Keperawatan, S2 Keperawatan, bahkan Doktor di bidang keperawatan, diharapkan dengan meningkatnya pendidikan akan diikuti dengan peningkatan kompetensi klinis dan kemampuan berkolaborasi (Martiningsih, 2011).

Menurut Curtis (2011) Sebagai tim kolaborasi, sangat penting bagi perawat dan dokter untuk dapat bertukar informasi dengan jelas dan komprehensif melalui pelaksanaan komunikasi. Pelaksanaan bertukar informasi ini dijelaskan oleh ketiga partisipan diwujudkan dengan saling share, konsultasi, konfirmasi, memberi masukan, bertanya jawab serta menyampaikan informasi baik secara langsung maupun melalui telepon. Hal tersebut sesuai dengan tujuan komunikasi antara perawat dan dokter yang tidak selalu untuk tujuan pengambilan keputusan bersama, melainkan sangat mungkin bertujuan untuk konfirmasi, penegasan atau memberi dukungan seperti yang telah dijelaskan oleh ketiga partisipan.

Pelaksanaan komunikasi secara efektif dan efisien sangat penting karena menjamin terlaksananya pemberian perawatan kesehatan yang aman dan berkualitas tinggi (Robinson, 2010). Kolaborasi perawat-dokter meningkatkan hasil klinis serta kepuasan bagi pasien, dapat mengurangi biaya rumah sakit (Ward, Schall, Sullivan, Bowen, Erdmann, \& Hojat, 2008), dan meningkatkan kepuasan bagi keluarga pasien, perawat, dan dokter (McGrail, Morse, Glessner \& Gardner, 2008).

Untuk mencapai sebuah untuk mencapai keberhasilan dan kualitas pelayanan kesehatan yang diberikan kepada pasien di rumah sakit, tentunya harus ada kemampuan kolaborasi antar profesi seperti profesi perawat dan profesi dokter. Ada banyak faktor yang mempengaruhi kolaborasi antara profesi salah satunya adalah pengalaman kerja. Pengalaman merupakan salah satu proses pemahaman untuk berperilaku yang disiplin, yang di peroleh dari pendidikan formal maupun non formal atau dianggap suatu proses yang bertujuan 
menciptakan kinerja yang lebih baik (Zainullah dkk., 2013). Adapun pengalaman kerja didefinisikan sebagai sesuatu atau kemampuan yang dimiliki oleh para karyawan dalam menjalankan tugas-tugas yang dibebankan kepadanya. Dengan pengalaman yang cukup panjang dan cukup banyak maka diharapkan mereka akan mempunyai kemampuan yang lebih besar daripada yang tanpa pengalaman. (Alex Nitisemito, 2005) Orang yang berpengalaman dalam bekerja memiliki kemampuan kerja yang lebih baik dari orang yang baru saja memasuki dunia kerja, karena orang tersebut telah belajar dari kegiatankegiatan dan permasalahan yang timbul dalam kerjanya.

Seperti kata pepatah bahwa pengalaman adalah guru terbaik. Pengalaman kerja karyawan menunjukan tingkat penguasaan keterampilan (softskill) karyawan. Hal ini di dukung oleh penelitian yang di lakukan oleh Martiningsih (2011) yang mengatakan bahwa ada hubungan antara pengalaman lama bekerja dengan sikap perawat dan dokter tentang praktik kolaborasi. Lama kerja sangat berkaitan erat dengan pengalaman-pengalaman yang didapat selama menjalankan tugas. Makin lama seseorang bekerja, kecakapan (pengetahuan) mereka akan lebih baik karena sudah menyesuaikan diri dengan pekerjaannya (Agus, 1992 dalam Martiningsih, 2011).

Kolaborasi perawat-dokter yang baik akan memberikan dampak yang positif baik bagi pasien sebagai penerima pelayanan kesehatan dan juga baik perawat dan dokter sebagai pemberi pelayanan. Menurut Larson 1999 dalam Setiawan 2013 dari segi pasien, kolaborasi perawat dan dokter yang terjalin dengan baik akan berpengaruh pada angka kematian yang lebih rendah. Kolaborasi perawat-dokter juga mempunyai pengaruh yang signifikan terhadap menurunkan hari perawatan dan biaya perawatan di rumah sakit (Baggs et al, 1999 dalam Setiawan 2013). Bagi perawat dan dokter, kolaborasi yang baik dapat menciptakan suasana dan lingkungan kerja yang harmonis dan dalam jangka panjang akan memberikan kepuasan kerja (Fagin, 1992 dalam Setiawan, 2013).
Berdasarkan studi pendahuluan yang di lakukan peneliti di rumah sakit gmim pancaran kasih manado di dapatkan hasil wawancara dengan 4 perawat. Perawat yang pertama mengatakan pengalamannya bekerja sebagai perawat sudah satu tahun lebih dan masih belum bisa berkolaborasi dengan baik karena belum memiliki pengalaman kerja yang lama, dan sering terjadi permasalahan antara perawat dan dokter. Untuk 3 perawat lainnya mengatakan sudah 25 tahun lebih bekerja di rumah sakit tersebut dan untuk kolaborasi dengan dokter sudah baik, akan tetapi biasanya keberhasilan dalam kolaborasi tergantung dari dokter, hal ini sesuai jawaban dari kuesioner yang di bagikan bahwa para perawat dokter dan perawat harus saling berkontribusi demi kebaikan dari pasien.

\section{METODE}

Desain penelitian merupakan rencana penelitian yang disusun sedemikian rupa sehinngga peneliti dapat memperoleh jawaban terahadap pertanyaan dari penelitian (Setiadi, 2013). Jenis penelitian yang digunakan ialah penelitian yang bersifat analitik dengan pendekatan cross sectional yaitu variabel independen dan variabel dependen akan dilakukan serta dikumpulkan secara bersama-sama (setiadi, 2013). Penelitian akan dilakukan Pada bulan Desember 2020 Penelitian ini akan dilaksanakan Di RSU GMIM Pancaran Kasih Manado.

Berdasarkan data awal yang di dapatkan peneliti dari RSU. GMIM Pancaran Kasih jumlah perawat yaitu sebanyak 158 orang perawat yang terdiri dari D3 sebanyak 76 orang dan S1 Ners sebanyak 82 orang. Pengambilan sampel dalam penelitian ini menggunakan metode simple random sampling adalah salah satu teknik random sampling dimana setiap anggota atau unit populasi mempunyai kesempatan yang sama untuk diseleksi sebagai sampel. Pengambilan secara acak sederhana ini dibedakan menjadi dua cara, yaitu dengan mengundi anggota populasi (lottery technique) atau teknik undian.

Pada penelitian ini menggunakan 
teknik undian yang memenuhi kriteria inklusi dan ekslusi (Notoatmodjo, 2012).

Pada instrumen pengalaman kerja menggunakan kuesioner yang di adopsi dari Nugroho (2012) dengan judul Pengaruh Motivasi Kerja, Disiplin Kerja Dan Pengalaman Kerja Terhadap Produktivitas Kerja Karyawan Pada Industri Kerajinan Topeng Di Dusun Bobung, Putat, Patuk, Kabupaten Gunung Kidul. Kuesioner ini terdiri dari 6 pernyataan dengan kriteria penilaian sangat setuju dengan nilai 4 , setuju dengan nilai 3 , tidak setuju dengan nilai 2 , dan sangat tidak setuju dengan nilai 1 di mana pengaktegorian di lakukan dengan perhitungan mean/median jika data normal maka menggunakan mean dan jika data tidak normal menggunakan median sehingga baik > Mean/Median dan kurang baik < Mean/Median. Pada kuisioner kemampuan berkolaborasi perawat dan dokter di adopsi dari Sitepu (2013) dengan judul Sikap Ners Dan Dokter Spesialis Tentang Kolaborasi Perawat Dokter Dan Kepuasan Kerja Dokter Spesialis Di Rsup $\mathrm{H}$ Adam Malik Medan. Koesioner selanjutnya menggunakan metode yang sama menggunakan kuesioner likert scale di mana responden di minta untuk memberikan pendapatnya mengenai Kemampuan Berkolaborasi Perawat dan Dokter. Instrumen ini terdiri dari 15 butir pertanyaan dengan criteria penilaian sangat tidak setuju di nilai 1 tidak setuju di nilai 2 setuju di nilai 3 sangat setuju di nilai 4 di mana Pengaktegorian di lakukan dengan perhitungan mean/median jika data normal maka menggunakan mean dan jika data tidak normal menggunakan median sehingga jika Baik > Meam/ Median dan kurang baik < Mean/Median.

Pengolahan data diperoleh dari hasil penelitian ini diolah secraa manual dengan mengelompokkan hasil dari kuisioner kemudian dilakukan analisis menggunakan uji statistic menggunakan system komputerisasi yaitu editing, coding, processing dan cleaning. Data lalu di uji statistic dengan menggunakan uji univariat dan bivariat.

\section{HASIL}

\section{Analisa Univariat}

Pada analisis univariat digambarkan tentang distribusi frekuensi pengalaman kerja perawat dan perspektif kolaborasi Perawat-Dokter.

Tabel 1 Distribusi Frekuensi berdasarkan pengalaman kerja

\begin{tabular}{llcc}
\hline Variabel & Kategori & F & \% \\
\hline \multirow{2}{*}{ Pengalaman Kerja } & Baik & 74 & 64,9 \\
\hline Total & Kurang Baik & 40 & 35,1 \\
\hline \multirow{2}{*}{$\begin{array}{l}\text { Perspektif Kolaborasi } \\
\text { Perawat-Dokter }\end{array}$} & Baik & $\mathbf{1 1 4}$ & $\mathbf{1 0 0 , 0}$ \\
\hline Total & Kurang Baik & 59 & 51.8 \\
\hline
\end{tabular}

Tabel 1 diatas menunjukkan distribusi frekuensi pengalaman kerja perawat dimana sebagian besar Perawat menjawab baik $(64.9 \%)$ pada pengalaman kerja dan distribusi frekuensi kolaborasi DokterPerawat dipersepsikan kurang baik oleh hamper $1 / 2$ Perawat dengan persentase $48.2 \%$. 


\section{Analisis Bivariat}

Analisis bivariate dilakukan dengan menggunakan uji Chi Square dan didapatkan hasil seperti pada tabel 2 dibawah.

Tabel 2. Hasil analisis bivariat

\begin{tabular}{|c|c|c|c|c|c|c|c|}
\hline \multirow{3}{*}{$\begin{array}{c}\text { Pengalaman } \\
\text { Kerja }\end{array}$} & \multicolumn{7}{|c|}{ Perspektif Kolaborasi Perawat-Dokter } \\
\hline & \multicolumn{2}{|c|}{ Baik } & \multicolumn{2}{|c|}{$\begin{array}{c}\text { Kurang } \\
\text { Baik }\end{array}$} & \multicolumn{2}{|c|}{ Total } & \multirow[t]{2}{*}{$\alpha$} \\
\hline & $\mathbf{F}$ & $\%$ & $\mathbf{F}$ & $\%$ & $\mathbf{F}$ & $\%$ & \\
\hline Baik & 45 & 68 & 29 & 39,2 & 74 & 100 & \multirow{2}{*}{0,008} \\
\hline $\begin{array}{l}\text { Kurang } \\
\text { Baik }\end{array}$ & 14 & 35 & 26 & 65 & 40 & 100 & \\
\hline Total & 59 & 51,8 & 55 & 48,2 & 114 & 100 & \\
\hline
\end{tabular}

Dari tabel 2 diatas hasil di peroleh nilai $\rho=$ 0,008 maka dapat disimpulkan bahwa ada Hubungan Pengalaman Kerja Perawat Dengan Perspektif Berkolaborasi Perawat Dokter Di RSU Gmim Pancaran Kasih Manado. Hal ini menandakan bahwa Pengalaman kerja yang ada di RSU Gmim pancaran kasih manado Baik, sehingga Perspektif Berkolaborasi Perawat - Dokter yang di dapatkan adalah baik.

\section{PEMBAHASAN}

Berdasarkan hasil penelitian yang dilakukan di RSU Gmim Pancaran Kasih Manado dengan jumlah responden 114 orang, sebanyak 74 orang $(64,9 \%)$ memiliki Pengalaman Kerja yang baik. Sedangkan 40 responden $(35,1 \%)$ dalam kategori kurang baik. Hal ini menandakan bahwa Pengalaman kerja perawat dalam keadaan yang baik karena memiliki pengalaman kerja yang baik. Hal ini di buktikan dengan jawaban responden di dalam kuesioner yang menjawab bertambahnya masa kerja seseorang, maka pengalaman kerja yang diperolehnya akan semakin banyak. Hal ini dapat membantu dalam meningkatkan kinerjanya. Hal ini dinyatakan oleh Armstong \& Baron dalam Wibowo (2011) bahwa pengalaman kerja merupakan salah satu elemen personal faktor yang mempengaruhi kinerja karyawan di perusahaan. Demikian pula pada hasil penelitian Kotur \& Anbazhagan (2014) yang menyimpulkan bahwa bertambahnya pengalaman kerja akan semakin meningkatkan kualitas kinerja.

Pengalaman kerja seseorang dalam melaksanakan tugas pada sebuah organisasi sangatlah penting perannya. Seorang yang memiliki pengalaman kerja lebih banyak tentu akan lebih mengerti apa yang harus dilakukan ketika menghadapi sebuah masalah yang muncul. Selain itu akan lebih cepat dalam bekerja dan tidak harus beradaptasi dangan tugas yang dijalankan kerena sudah memiliki pengalaman. Sehingga organisasi akan lebih mudah mencapai tujuan organisasi kerena didukung oleh semua yang sudah berpengalaman di bidangnya masingmasing.

Pengalaman kerja tidak hanya menyangkut jumlah masa kerja, tetapi lebih dari juga memperhitungkan jenis 
pekerjaan yang pernah atau sering dihadapi. Sejalan dengan bertambahnya pekerjaan, maka akan semakin bertambah pula pengatahuan dan ketrampilan seseorang dalam bekerja. Hal tersebut dapat dipahami karena terlatih dan sering mengulang suatu pekerjaan sehingga kecakapan dan ketrampilan semakin dikuasai secara mudah, tetapi sebelumnya tanpa latihan, pengalaman-pengalaman yang pernah dimiliki akan menjadi berkurang bahkan terlupakan.

Berdasarkan hasil penelitian yang dilakukan di RSU Gmim Pancaran Kasih Manado dengan jumlah responden 114 orang, sebanyak 59 orang $(51,8 \%)$ memiliki kolaborasi yang baik. Dan 55 responden $(48,2 \%)$ memiliki kolaborasi kurang baik. Hal ini menandakan Perspektif kolaborasi perawat-dokter yang ada di RSU Gmim pancaran kasih manado sudah cukupbaik dengan adanya hasil penelitian yang menunjukan Perspektif Kolaborasi Perawat-Dokter Lebih banyak baik dari pada kurang baik. Kolaborasi dapat berjalan baik jika setiap anggota saling memahami peran dan tanggung jawab masingmasing profesi memiliki tujuan yang sama, mengakui keahlian masing-masing profesi, saling bertukar informasi dengan terbuka, memiliki kemampuan untuk mengelola dan melaksanakan tugas baik secara individu maupun bersama kelompok.

Terwujudnya suatu kolaborasi tergantung pada beberapa kriteria, yaitu adanya saling percaya dan menghormati, saling memahami dan menerima keilmuan masing-masing, memiliki citra diri positif, memiliki kematangan professional yang setara yang timbul dari pendidikan dan pengalaman, mengakui sebagai mitra kerja bukan bawahan, keinginan untuk bernegoisasi Pelaksanaan kolaborasi tidak hanya bermanfaat bagi pasien tetapi juga akan memberikan kepuasan kepada tenaga kesehatan karena kolaborasi akan meningkatkan dan mengoptimalkan peran serta aktif antara perawat dan dokter dalam pengambilan keputusan tentang pengobatan dan perawatan berfokus pada kebutuhan pasien secara komprehensif dengan memperhatikan kontribusi masingmasing (Herbert,2005 \& Ushiro, 2009).

Hasil penelitian ini di dapatkan hasil hubungan antara pengalaman kerja dengan Perspektif Kolaborasi Perawat-Dokter dengan hasil Pengalaman Kerja yang baik 45 responden $(60,8 \%)$ dengan Perspektif Kolaborasi Perawat-Dokter dalam kategori baik sebanyak 14 responden $(35,0 \%)$ dan ada Hubungan Pengalaman Kerja Perawat Dengan Perspektif Berkolaborasi PerawatDokter Di RSU Gmim Pancaran Kasih Manado. Hal ini menandakan bahwa Pengalaman kerja yang ada di RSU Gmim pancaran kasih manado Baik, sehingga Perspektif Berkolaborasi Perawat - Dokter yang di dapatkan adalah baik.

Kerjasama interprofesi dokter dan perawat yang efektif memerlukan adanya pemahaman yang benar tentang kolaborasi interprofesi dan penguasaan kompetensi adalah inti praktek kolaborasi. Elemen dalam koloaborasi efektif meliputi saling menghargai, komunikasi, assertive, tanggung jawab, kerjasama, tanggung jawab dan otonomi, Melalui kolaborasi efektif perawat-dokter dalam tim,adanya pengetahuan dan skill atau keahlian dari dokter dan perawat akan saling melengkapi. Pasien akan mendapat keuntungan dari koordinasi yang lebih baik melalui kolaborasi interprofesi.

Kerja sama tim dalam kolaborasi adalah proses yang dinamis yang melibatkan dua atau lebih profesi kesehatan yang masing-masing memiliki pengetahuan dan keahlian yang berbeda, membuat penilaian dan perencanaan bersama, serta mengevaluasi bersama perawatan yang diberikan kepada pasien. Hal tersebut dapat dicapai melalui kolaborasi yang independen, komunikasi yang terbuka, dan berbagi dalam pengambilan keputusan (Xyrinchis\& Ream, 2008 : WHO, 2010) Pendekatan kolaborasi yang masih berkembang saat ini yaitu interprofessional collaboration (IPC) sebagai wadah dalam upaya mewujudkan 
praktik kolaborasi yang efektif antar profesi. Hambatan dalam kolaborasi antar petugas kesehatan terutama antara dokter dan perawat menjadi penyebab kejadian yang akan menimbulkan kerugian dan bahaya, bahkan dapat mengancam jiwa pasien. Hambatan dalam kolaborasi dapat menjadi penyebab utama terjadinya medical error, nursing error atau kejadian tidak diharapkan (KTD). Pelaksanaan kolaborasi tidak hanya bermanfaat bagi pasien tetapi juga akan memberikan kepuasan kepada tenaga kesehatan karena kolaborasi akan meningkatkan dan mengoptimalkan peran serta aktif antara perawat dan dokter dalam pengambilan keputusan tentang pengobatan dan perawatan berfokus pada kebutuhan pasien secara komprehensif dengan memperhatikan kontribusi masing-masing (Herbert,2005 \& Ushiro, 2009).

\section{SIMPULAN}

Dari hasil penelitian ini maka dapat disimpulkan ada hubungan antara pengalaman kerja Perawat dengan perspektif kolaborasi Perawat-Dokter. Dimana didapatkan semakin baik persepsi terhadap pengalaman kerja maka semakin baik pula hubungan kolaborasi PerawatDokter yang dipersepsikan oleh Perawat. Hasil penelitan ini diharapkan dapat menjadi masukan bagi Rumah Sakit untuk memperkuat kolaborasi antar tenaga kesehatan.

\section{DAFTAR PUSTAKA}

Alex, S, Nitisemito. (2005). Manajemen Personalia (Manajemen Sumber Daya Manusia), Edisi Ke-5 Cetakan Ke-14, Galia Indonesia, Jakarta.

Anggarawati \& Sari. (2016). Kepentingan bersama perawat-dokter dengan kualitas pelayanan keperawatan. Jouurnal ilmiah kesehatan keperawatan, Volume 12, No 1, Februari 2016.

Arisha, Yona, Tanu. (2017). Apa saja peran perawat (Role of nurse) sebagai tenaga

medis https://www.dictio.id/t/apa-sajaperan-perawat-role-of-nurse-sebagaitenaga//5359

Budiono \& Surmirah, B. P. (2016). Konsep dasar keperawatan. Jakarta:Bumi Medika

Chalimatus Sa'adiyah, Hermin Endratno. (2013). Pengaruh pengalaman kerja, motivasi intrinsic dan kepuasan kerja karyawan terhadaap kinerja karyawan depo pelita satria perkasa sokaraja. Journal Bisnis dan manajemen issn 2338-9729 volume.1 no. 1 halaman 74-86

Curtis, K. \& Tzannes, A. (2011). How to talk to doctors-a guide for effective sommunication. International nursing review, 58,13-20

Efendi, F. (2014). Undang-undang republik Indonesia nomor 38 tahun 2014 tentang Keperawatan indonesiannursing.com/undangundang-republik-indonesia-no-38tahun 2014-tentang-keperawatan/

Kolaborasi Tenaga Kesehatan untuk peningkatan mutu pelayanan kesehatan. (2015). //https://www.mutupelayanankesehat an.net/22-edtorial/1851-kolaborasitenaga-kesehatan-untuk-peningkatan -mutu-pelayanan

LeTourneau, B. (2004). Physician and nurses: friends or foes. Journal of Health care manajemen, 49(1), 5-12.

Martiningsih, W. (2011). Praktik kolaborasi perawat-dokter dan faktor yang mempengaruhinya. Poltekes Kemenkes Malang, Prodi Keperawatan Blitar.

McGrail, K. A., Morse, D. S., Glessener, T., \& Gardner, K. (2008). What is found there: Qualitative Analysis of physician-nurse collaboration stories. Journal Gen Intern Med, 24(2), 198204

Mesmer, P. R. (2008). Enhancing NursePhysician collaboration using pediatric simalation. The Journal of Continuing Education In Nursing, 39(7), 319-327 
Jurnal Keperawatan, Volume 9, No. 2, Agustus 2021, (Hal. 24-32)

Muntoha, Ragil. (2015). Hubungan beban kerja dengan perilaku caring perawat di ruang perawatan khusus $R S U D d r$ $R$. Goeteng Taroenadibrata Purbalingga

Notoadmodjo, S. (2012). Metodologi penelitian kesehatan. Jakarta : Rineka Cipta

Notoadmodjo, S. (2010). Metodologi penelitian kesehatan. Jakarta : Rineka Cipta

Nugroho, Fitriyanto. (2012). Pengaruh Motivasi Kerja, Disiplin Kerja Dan Pengalaman Kerja Terhadap Produktivitas Kerja Karyawan Pada Industri Kerajinan Topeng Di Dusun Bobung, Putat, Patuk, Kabupaten Gunung Kidul

Ridar, I., Santoso, A. (2018). Peningkatan komunikasi dalam pelaksanaan interprofessional collaboration melalui catatan perkembangan pasien terintegrasi. Universitas Diponegoro Semarang

Robinson, F. Patrik, Gorman G., Lynda W. Slimmer and Rachel Yudkowsky. (2010). Perceptions of Effective and Ineffective nurse-physician communication in hospitals. Nursing forum, $45,3$.

Setiadi. (2013). Konsep dan Praktik Penulisan Riset Keperawatan Edisi 2. Yogyakarta: Graha Ilmu.

Setiawan A. \& Saryono.(2010). Metodologi penelitian kebidanan. Nuha Medika. Jakarta. 